\title{
Comparative genomics of resistance of spruce to the white pine weevil in British Columbia
}

\author{
Kermit Ritland ${ }^{1 *}$, Sébastien Verne ${ }^{1}$, Barry Jaquish ${ }^{2}$, Carol Ritland ${ }^{1}$ \\ From IUFRO Tree Biotechnology Conference 2011: From Genomes to Integration and Delivery \\ Arraial d Ajuda, Bahia, Brazil. 26 June - 2 July 2011
}

We present results of two large scale comparative studies of the genomic basis of resistance of Interior spruce to the white pine weevil. Both volume growth, the main objective of the spruce breeding program in British Columbia, and white pine weevil resistance, are examined. "Interior spruce" is a species complex involving mainly Picea glauca (White spruce) but introgressed with $P$. engelmannii (Englemann spruce), depending upon locality. In the first study, we compared constitutive expression of 17825 genes between 20 resistant and 20 susceptible trees to the weevil; 54 upregulated and 137 downregulated genes were found in resistant phenotypes, with implications discussed in regard to volume growth. In particular, we will be surveying these genes for SNPs that differ between these two classes of trees in the next year. In the second study, we developed a 1536 Illumina SNP chip based upon candidate genes for weevil resistance. In a novel experimental design, we assayed 945 open-pollinated progeny of the Prince George breeding population (176 parents), and 654 open-pollinated progeny of the Prince Rupert breeding population (134 parents); parents were also genotyped. Within each family of 100 progeny, we identified the highest ranked 3 progeny and the lowest ranked 3 progeny, based upon BC Ministry of Forests scores for volume growth and resistance. These were genotyped and used in a novel test analogous to the transmission disequilibrium test to detect both SNP associations and QTLs linked to SNP markers. Discoveries about associations and QTL are discussed, with the added caution about genotyping error. Both studies illustrate how operational tree breeding populations can provide valuable inferences about tree genomics.

* Correspondence: kermit.ritland@ubc.ca

${ }^{1}$ University of British Columbia, USA

Full list of author information is available at the end of the article
Author details

${ }^{1}$ University of British Columbia, USA. ${ }^{2}$ Ministry of Forests, Lands and Natural Resource Operations, USA.

Published: 13 September 2011

doi:10.1186/1753-6561-5-S7-010

Cite this article as: Ritland et al: Comparative genomics of resistance of spruce to the white pine weevil in British Columbia. BMC Proceedings 2011 5(Suppl 7):010.
Submit your next manuscript to BioMed Central and take full advantage of:

- Convenient online submission

- Thorough peer review

- No space constraints or color figure charges

- Immediate publication on acceptance

- Inclusion in PubMed, CAS, Scopus and Google Scholar

- Research which is freely available for redistribution
C Biomed Central
C Biomed Central 